\title{
On The Trinity Western University Controversy: An Argument for a Christian Law School in Canada
}

\author{
Dwight Newman ${ }^{\star}$
}

\section{Introduction}

Over the past number of months, the proposed new law school at Trinity Western University (TWU) has come under significant attack, including by many whom I count as academic colleagues within the Canadian Association of Law Teachers and by many within the Canadian law school community more generally. ${ }^{1}$ These attacks have had the unique effect of subjecting TWU's law school to a different approval process than has been used for any other Canadian law school, with a dual-committee structure to apply additional scrutiny to it. ${ }^{2}$ Some have put their attacks explicitly in longer forms, ${ }^{3}$ and many others have signed petitions against TWU. ${ }^{4}$

Let me say at the outset that I do take the critics of TWU to be sincere and to be operating in good faith based on their perceptions of the implications of shared human rights traditions, often building upon a deep awareness of experiences of historic discrimination against and oppression of individuals and groups. They also properly see religious beliefs as having public implications. ${ }^{5}$ As a result, it is important to face the critics' challenges both respectfully and seriously. There is also no doubting that the positions critical of TWU have much traction within the context of today's highly secularized legal and political culture. ${ }^{6}$ However, I will nonetheless be arguing against these critics and, with respect, I consider their position erroneous and dangerous.

It is important to highlight a fact that ultimately has very significant implications: the attacks tend to be framed against the very opening of TWU's law school ${ }^{7}$ - based on the extraction and decontextualized presentation of fragments of the school's community covenant. ${ }^{8}$ The attacks against TWU have appeared in many fora and from various sources, but the two most commonly referenced versions of the attacks have been the brief statement put forward by the Canadian Council of Law Deans seeking a regulatory response to the school ${ }^{9}$ and the longer paper published recently by Elaine Craig in the Canadian Journal of Women and the Law. ${ }^{10}$ The latter of these presents the most sustained and influential criticism of TWU and it will thus serve as a foil for some of my arguments here. In treating it as such, I admit that there are some uncertainties of interpretation on points in Craig's article and I attempt to read her arguments as fairly as I can.

In this article, I will challenge the reasoning employed by these critics as being - at least inadvertently - lacking in a spirit of full academic enquiry and in the values of openmindedness to which the critics themselves would generally seek to adhere. I will argue that the methodological approach of TWU's critics risks falling into - putting the point bluntly - 
stereotyped conceptions of a particular group, that being Evangelical Christians. Furthermore, I contend that this approach amounts to advocacy for limitation on the rights of Evangelical Christian communities that fails to take into account the means normally employed for analyzing rights conflicts. Insofar as these problems exist in their criticisms of TWU, the criticisms should not stand.

\section{The Potential Contribution of a Christian Law School}

The argument for TWU, is not a solely defensive argument. It is important to contextualize the issue by beginning first with an affirmative case for the unique and important contribution that could be made to Canadian legal education, currently consisting only of an increasing number of secular law schools, ${ }^{11}$ by a Christian law school. Although it has gone largely undiscussed in the public discourse around TWU, there is in fact a significant scholarly literature in the United States on the contribution offered by religious law schools. I wish to highlight three points from that literature as identifying contributions that a school like TWU has the potential to make. ${ }^{12}$

First, religiously oriented law schools have the potential to increase the accessibility of legal education to students who may not be well served by existing, secular law schools. An example is illustrative of the point. The well-respected Cardozo Law School is based at Yeshiva University, a Jewish university, although Cardozo itself is certainly open to a diverse group of students. Unlike the undergraduate programs at Yeshiva University, Cardozo does not necessarily incorporate more Jewish law in its curriculum than many other American law schools already have. ${ }^{13}$ However, by operating in a manner consistent with Orthodox Jewish practice - through full closure of the law school during the Jewish Shabbat/Sabbath and during all Jewish religious holy days, ${ }^{14}$ for example, as well as other steps such as the availability of kosher food - Cardozo becomes a far more comfortable place for Orthodox and/ or some other observant Jews than other law schools. ${ }^{15}$
Some of the writing on Cardozo has suggested that these ritual-related concerns may not be as significant for Christians, since they may have fewer practical ritual obligations and those that they do have may be more accepted within the general culture. ${ }^{16}$ However, I suggest that there may be more to be explored. While it is true that Christian holidays, for example, are better accommodated by the typical academic schedule than those of other religions, the questions raised by Cardozo suggest that a focus on ritual is not necessarily a focus on ritual as such. It is, in fact, a focus on particular matters of greater concern. For many Evangelical Christians, such matters of greater concern are not ritual. ${ }^{17}$ To the extent this is so, if those other elements within Evangelical Christian practice, such as religious community, are not well-accommodated at secular law schools, then the accessibility of legal education is a pertinent factor.

My question, in part, is whether there would necessarily be an application from an Evangelical Christian law school if every law school in Canada had always been fully welcoming to Evangelical Christians. How do law school classrooms treat a new student who refers to his or her faith at any point in discussions? How do law professors generally deal with a student who wants to talk about justice in a manner informed by faith traditions rather than a manner that is simply informed using a positivist analysis of cases? Is the social environment of the typical Canadian law school welcoming to those of faith such as Evangelical Christians? When Canadian law schools try to shut down an Evangelical Christian school, they might wish also to explore how their practices might have adverse effects on students of faith and on the accessibility of legal education to different communities. ${ }^{18}$

Second, the development of religiously based law schools opens the possibility of new forms of legal scholarship. Secular law schools have long patterns of devaluing religious thought and that devaluation puts significant pressures on younger scholars, particularly in their formative years that correspond to the period during which they are under subject to review for tenure and promotion. ${ }^{19}$ However, there is little doubting 
that there are important scholarly contributions to be made to an understanding of law through the bringing to bear of faith-based perspectives. ${ }^{20}$ Some of the scholarship that may emerge could consist of matters such as retrieval of lost cultural starting points. ${ }^{21}$ For example, leading secular writers on the rule of law, writing with the finest scholarly publishers, have tended to characterize the concept of the rule of law as having its earliest origins in Greek democratic practice. ${ }^{22}$ Yet Christian legal scholarship is able to point to the rule of law model embodied in scriptural texts on Israelite kingship, notably Deuteronomy 17, ${ }^{23}$ offering a simple historical corrective not available without engagement with Judeo-Christian faith traditions. ${ }^{24}$ Perhaps more broadly, Christian legal scholarship and legal education would be engaged with many of the very things that secular legal scholars and educators claim to be trying to do, whether to reconstructing the role of narrative or considering different models for dispute resolution. ${ }^{25}$

Third, and building upon this point, Christian legal scholarship brings a distinctive valuesbased engagement with legal thought that is often sorely lacking. ${ }^{26}$ The lack of values-based engagement actually more broadly risks diminishing what secular educational institutions can accomplish in ways that have been the subject of recent concern by the likes of John Sommerville in The Decline of the Secular University. ${ }^{27}$ Sommerville points to how Christian perspectives may have important contributions to make to the law, noting that " $[\mathrm{t}]$ he central problem in law is a doctrinal one, a question of how we should relate to each other. ${ }^{28}$ Interestingly, aside from its place within the law, that is a very central question within faith traditions.

To that question, those bringing faith perspectives may bring important perspectives and values not always found in the case law, at least on its surface. For example, do discussions of the values of compassion, of generosity, or of humility feature prominently in the law school lecture theatre? A religious law school may contribute to the development of graduates focused genuinely on work in the non-profit sector, an area other law schools claim to be interested in support- ing but do surprisingly little to support. Such a school may also be able to communicate about values in ways that resonate with a larger public put off by the perceived values of lawyers and secular law schools. To mention just one example, increasing Evangelical attention to theologies of environmental stewardship may bring to bear values that resonate with a broader public in the development of environmental law. ${ }^{29}$ In various ways, the legal scholarship that could be fostered at a Christian law school has very significant potential to make important contributions.

\section{Considering Christian Thinking in an Open-Minded Manner}

Having put something of a positive case for what a Christian law school can contribute, I want to face a first instance of the lack of full academic enquiry present in the critics' attacks. Elaine Craig references the priority given to Scripture in TWU's core value statements and then suggests that such a policy means that TWU is therefore incapable of teaching critical thinking skills. ${ }^{30}$ There is slightly more argument on the point but there is, for instance, no evidence-based argument for the proposition that effectively amounts to a claim that Christians cannot think critically unless they are prepared to abandon their faith through the process of "critical thinking." As Craig puts the point bluntly, "to teach that all judgment must be guided by the Bible - to teach that the source of truth for all ethical decision making is the scripture - is not to teach the skill of critical thinking about ethical issues." 31 Here is an academic paper about TWU that does not actually explore what such an environment might be like. Craig's argument does not explore the critical thinking of those within broad Christian scholarly traditions at many institutions scholars who would describe themselves as using faith to illuminate reason but who still engage in extensive critical reasoning. ${ }^{32}$ Furthermore, such an argument does not engage in any exploration of how scholarly Evangelicals might engage with Scripture.

I cannot claim to offer any complete analysis on these points in the scope of a short dis- 
cussion of this sort, but I will make three points that challenge Craig's dismissal of Evangelicals as unengaged in critical thinking. ${ }^{33}$ First, there is in fact scholarly literature examining the development of critical thinking skills in those educated in Evangelical Christian environments. Some evidence points toward an equal or possibly even greater acquisition of critical thinking skills than in secular environments. Admittedly, sometimes the focus on critical thinking skills in Christian education is to help in the defence of claims against non-Christian challenges, but there are also strong human developmental reasons within Christian traditions for a commitment to critical thinking. ${ }^{34}$

Second, there are many important works on Christian scholarly traditions and different ways in which those traditions may be informed by Scripture as an authoritative guide. Interpreting Scripture is a matter that requires various perspectives - it is not a process of identifying simple propositions. ${ }^{35}$ There are internal dialogues within these traditions on the text, with longstanding recognitions, for example, that different parts of law stated in the scriptural law may be distinguished between ceremonial law, civil law, and moral law, with some of these time-bound and others not, and sometimes debate on which is which. ${ }^{36}$ There is room for serious ongoing conversations within Christian scholarly traditions, just as has been the case at many universities through the centuries.

Third, the work of scholarly Evangelicals is entirely consistent with the possibility of engaging with the Bible in a variety of ways within a faith tradition. There is a very different scholarly Evangelical tradition than many might assume, ${ }^{37}$ which will generally not correspond to the stereotype of individuals plucking out random Biblical verses and then applying them all in a literalistic form. For example, a major emphasis in much recent Evangelical writing is on the scriptural text as composed of parts with different genres, making it appropriate to reflect carefully on what guidance is to be taken from what sorts of books and the genres of writing that they present. ${ }^{38}$ That sort of claim is not one derived only from recent Evangelical writing but has been at least implicitly present in prominent texts for at least decades. ${ }^{39}$ An approach to interpretation that considers the genre of texts is a sophisticated approach that differs from the stereotypes and that shows critical thinking even in the interpretive exercise.

The fact that somebody commences with faith of some sort should not be a basis for excluding that individual from the realm of critical thinking. To exclude some from the realm of critical thinking works real harm against them and does not seek to understand them. The argument frankly reflects a perspective that, as I say, has not engaged fully in seeking to understand that on which it comments and the living tradition being carried on within Christian scholarly environments.

That said, I am not trying to defend freedom for religious educational institutions on the basis that they will not do anything different with it than secular institutions. Defending freedom only for those who will not do anything differently would not really be a defence of freedom. Nonetheless, it is an important starting point to notice that there has been very little sustained effort by critics to engage with what an Evangelical school might actually be like, and I think this point carries over to other dimensions of the issues.

\section{The Community Covenant and Rights Reconciliation}

The background presented in prior sections is important to understanding the value that a Christian law school has the potential to bring. This context also points to some of the ways in which critics have unfairly stereotyped and prejudged Evangelical Christian communities as being incapable of engaging in critical thinking. It offers a vital framework in which TWU's community should be recognized as having value. Understanding that point, and the rights that belong to that community, is important to answer how to deal with the conflicting rights claims associated with the sexuality-related clause of the community covenant. 
It is understandable that critics have expressed concerns about the sexuality-related component of TWU's community covenant, and I have no doubt it reflects their good faith effort to engage with questions of justice and equality. Those who are sensitized to rights and equality issues will no doubt have seen within Western societies many instances in which individuals claiming to be acting on Christian values have done very unjust and, indeed, unchristian things in their discriminatory and, sadly, even hateful interactions with, for instance, those with an LGBT identity. However, just as experience with particular individuals from a faith tradition should not drive a prejudgment of a whole faith tradition's necessary approaches, there needs to be careful thought here on the engagement with the living tradition of a faith community in terms of rights reconciliation.

If enacted by a governmental body, the community covenant would of course contain objectionable restraints of various sorts on individual freedom. A government body, however, does not enact the covenant. It is, instead, a holistic set of expectations about behaviours within a privately funded living faith community that has asked to be able to engage in legal scholarship and legal education. ${ }^{40}$ There will be many people, for a variety of reasons, who would not comply with its expectations on behaviours and will not be members of that community. By the same token, some will indeed sign on to that community covenant as members of the TWU community, and their religious association right (or collective religious freedom right $)^{41}$ cannot be simply ignored. There is a rights conflict that arises because of rights claimed by those with LGBT identities who wish to attend TWU's law school while asking the living faith community at TWU to change its traditions. They seek changes so that anyone may attend while engaging in sexual activities that are legal under Canadian law but not permitted under the community covenant that reflects the living faith traditions of the community.

The leading approach to rights conflicts within Canadian law is one of attempting to reconcile conflicting rights rather than to prioritize one right over another. This sort of emphasis appears present in the Supreme Court of Canada's past decision concerning TWU and the British Columbia College of Teachers. ${ }^{42}$ It is explicitly and recently present in the majority approach in N.S., ${ }^{43}$ a case concerning a claim by a sexual assault complainant to wear a religious veil while testifying in court. In that latter case, there was a real conflict between a religious freedom right and a right to full answer and defence. Even in the context of a conflict with a basic procedural right related to trial fairness, Chief Justice McLachlin's majority judgment explicitly indicates that reconciliation of competing rights claims through mutually modificatory interpretation of those rights is the preferred option for analysis of conflicting rights, with "balancing" of rights then only a last-resort option. ${ }^{44}$

In her recent book on freedom of religion, ${ }^{45}$ Mary Anne Waldron is somewhat more sceptical of what propositions of this sort have become already embodied in Canadian freedom of religion jurisprudence. Despite this concern, she rightly identifies a key reason for preferring reconciliation of rights over balancing of rights in the context of such conflicts. Waldron notes that when we understand the whole spectrum of human rights as interconnected, the process of 'balancing' may occur in such a manner as to have a first right eliminate a second right. In such cases, the process actually negates the underlying bases of the second right and thus the basis for all rights' existence. ${ }^{46}$

In thinking about reconciling rights in the TWU context, one must consider a living tradition, a community carried on with private funding, up against the claims of others to join its institutions. The latter group claim a right to violate agreed moral tenets of those operating within the lived tradition and lived community. ${ }^{47}$ Our rights reconciliations in such contexts have in fact typically drawn sharp distinctions between the decisions of state institutions to exclude individuals and the decisions of privately funded associations to exclude individuals in contexts where the exclusions are in tension with equality claims. There are reasons for this differentiation, of course, in the proper roles of the state as opposed to the proper limits on the 
state in its requirement on individuals' private lives to embody the same approach to equality. ${ }^{48}$

Stuart White, while advancing the discussion in the context of political theory, has offered a framework that I would suggest is actually descriptive of the sort of reconciliation applicable within legal contexts. He proposes a framework that considers the competing roles of integrity interests and opportunity interests. In other words, he proposes a framework more nuanced than one which claims that there is never a right to exclude in a manner that affects equality interests. A women's gym, for example, can exclude men because there is no genuine loss of opportunity by the men, who have other options. White suggests that any purpose-protecting exclusion rule receives some degree of deference, unless overruled by opportunity interests of individuals negatively affected by the exclusion, but with the possibility that these interests can in turn be overruled by individuals' integrity interests. ${ }^{49}$

In the circumstances of TWU, it is both the case that (1) those with an LGBT identity who wish to maintain sexual practices in accordance with that identity that do not comply with the TWU community covenant have other opportunities to attend any of a number of other law schools; ${ }^{50}$ and that (2) even if one disagrees with the interpretation of the faith tradition embodied within TWU's community covenant, that is the choice of interpretation that TWU, as a community, has made to this point in time. Both factors actually weigh in favour of TWU being able to exclude based on the community covenant provision, even if the exclusions have what would elsewhere be called adverse discrimination effects. Recognizing this point is not an easy one for those committed to equality as a central value, but all rights must be subject to reconciliation with other rights if any rights are to mean anything at all. When rights conflicts arise, it is necessary to read each right in a way that fits with other rights. Mutual modification between religious freedom rights and equality rights follows, in part, a public-private divide and, in part, an interest analysis looking to the nature of the interests affected.
Respect for the religious freedom of a faith community must, in the circumstances of TWU, allow it to carry on with its community covenant. That does not mean that there cannot be non-legal challenges put to TWU, asking it to justify its policy. Moral discourse is part of freedom. There may well even be internal challenges within the faith tradition that ask TWU to consider, for instance, whether its objectives might be met by presenting a clear Evangelical Christian viewpoint in its scholarship and teaching without regulating the conduct of students in the particular way that the community covenant does. ${ }^{51}$

A challenge that might be put within that discussion is how TWU would see its role in interacting with a potential student who subscribes to TWU's tradition and covenant in every respect but for a sincere disagreement on what Scripture implies on same-sex relationships. What if this potential student struggles to fit in as an Evangelical Christian at secular law schools but cannot attend TWU due to the conflict between a longterm committed same-sex relationship and the community covenant? ${ }^{52}$ Would this student be less worthy of attendance at TWU than another student who does sign the community covenant under parental pressure but is secretly ignoring the practices to which he or she has subscribed? There are serious questions to ask here, relating generally to the appropriate Christian response to those with LGBT identities who genuinely seek to live as faithful Christians but who genuinely disagree on the interpretation of Scripture on matters related to same-sex relationships. When does a loving, Christian response actually require exclusion for the maintenance of the Christian community's living tradition and when can a loving, Christian response allow inclusion even while potentially challenging the member's views?

I do not purport to have easy answers to a number of the challenging questions raised in the context of the TWU controversy. However, my point remains that discourses within the tradition may produce change over time, precisely because of the kind of view I offered earlier of the richness of Christian traditions. Any 
such changes, however, must be based on what TWU concludes is right rather than based on a state-sanctioned rights claim against it. ${ }^{53}$ Given our standard reconciliation of rights model, even though some challenging results ensue, the sphere of private religious freedom is one on which the state must not intrude.

On the current interpretation of the community covenant, it is of course clear that TWU has some perspectives, presumably to be discussed in the classroom, that are not in accordance with existing positive Canadian law. However, the public gatekeeper role of the legal profession cannot properly be used to exclude from the legal profession those who have dared to discuss different perspectives on the law or even possible law reform. It may turn out that TWU's perspectives on particular points of the law do not survive. However, if professors' criticism of existing law is grounds for exclusion of a law school's graduates from the legal profession, there is a long line of law faculties at risk. Each law school must be allowed that freedom of thought and discourse, whether secular or religious, unless there is actually affirmative evidence that its graduates are committed afterward to actual non-compliance with the law. ${ }^{54}$

Craig writes near the end of her article as if the American Bar Association's rules would preclude a law school in similar circumstances as TWU, despite the relatively meaningful religious school exceptions that they contain..$^{55}$ What she does not address is that subsequent to the elaboration of the latest ABA text to which she refers, and thus contrary to her suggestions, the ABA went ahead and accredited a new religious school, Faulkner's Thomas Goode Jones's School of Law, that has provisions for student expectations that are very similar to TWU's - and seemingly without the controversy that some writers had expected. ${ }^{56}$ The American experience of religious schools reflects a profound respect for religious diversity, a living together in difference, from which Canadians can learn much.

A Christian law school has the potential to make a very significant contribution to Canadian legal scholarship and legal education. The critics who have attacked it do not engage seriously with what it might be like, instead relying on stereotyped prejudgments. They have not grappled with standard approaches to rights reconciliation, which give ample reason to respect a school like TWU's religious freedom and its rights to open and operate. With the greatest of respect for the deep-seated commitment to equality of TWU's critics, I challenge the critics to think seriously upon what is at stake in terms of freedom and to recognize the place of the new law school proposed as one school amidst the plurality and diversity of Canadian legal education.

\section{Endnotes}

* Professor of Law, University of Saskatchewan; B.A. (Regina), J.D. (Saskatchewan), B.C.L., M.Phil., D.Phil. (Oxford). A prior version of this paper was presented at the Canadian Association of Law Teachers (CALT) Annual Meeting in Victoria, British Columbia, on 4 June 2013. I am grateful to Janna Promislow for organizing the panel at which the paper was presented. I am grateful for the ideas raised by Gillian Calder in a presentation on the other side of the issue within the same panel and wish to express my appreciation for the very respectful discussion at the panel. I am also grateful for other comments or interactions on the topic that have helped me with my argument prior to, during, and/or after the panel presentation from Iain Benson, Andrée Boiselle, John Carpay, Paul Clarke, Brent Cotter, Carol Crosson, Chris Donald, Neil Foster, Gwen Landolt, Robert Leckey, Janet Epp Buckingham, Paul Clarke, Robert Diab, Alvin Esau, Grant Huscroft, John Kleefeld, Sonia Lawrence, Sonya Lalli, Roderick Macdonald, Preston Manning, Carissima Mathen, Brad Miller, Richard Moon, Ken Norman, Nicole O'Byrne, Patricia Paradis, Michael Plaxton, Shauna Van Praagh, David Sandomierski, Kevin Sawatsky, John Wade, Mary Anne Waldron, Grégoire Webber, and John Whyte. I also thank Lorelle Binnion and Michelle Biddulph for reading a nearcomplete draft and providing useful comments and challenges. I must also acknowledge that the theologically oriented points within the paper would be much weaker than they are without teaching from Iain Provan and Andrew Lewis, although they have not had any discussion with me on this text or this argument more generally. On all matters, I note simply that those who have 
commented do not necessarily agree with my conclusions, and I take full responsibility for all errors and weaknesses in the argument.

1 Apart from law professors themselves (as well as some lawyers of similar viewpoints, such as Clayton Ruby), many public commentators who have taken a position on the issue have defended the opening of TWU's law school. See e.g. Jonathan Kay, “The Case for Trinity Western University's Christian Law School", National Post (23 January, 2013) online: National Post <http://fullcomment. nationalpost.com/2013/01/23/jonathan-kay-thecase-for-trinity-western-universitys-christianlaw-school/>; Barbara Kay, "Law Deans' Position on Trinity Western Would Shut Every Law School in Canada", National Post (25 January 2013) online: National Post < http://fullcomment.nationalpost. com/2013/01/25/barbara-kay-law-deans-position-on-trinity-western-would-shut-every-lawschool-in-canada/>; John Carpay, "A Free Society Should Tolerate a Christian-Based Law School", Vancouver Sun (21 January 2013) online: Vancouver Sun <http://www.vancouversun.com/life/ free+society+should+tolerate+Christian+based+ school/7851191/story.html>; Editorial, "Critics of Christian Law School Are Bigots, Too", Vancouver Province (23 October 2013) online: The Province <http://www.theprovince.com/life/ Critics+Christian+school+bigots/9070458/story. html>. I have been amongst these commentators previously: Dwight Newman, "Canadian Law Deans Attack Right to Religious Diversity", Vancouver Sun (21 January 2013) online: Vancouver Sun <http://www.vancouversun.com/ health/Canadian+deans+attack+right+religious+ diversity/7851195/story.html>. The British Columbia Civil Liberties Association also came out in support of TWU around the same time period in late January 2013, and well-known lawyer Eugene Meehan has also defended the school's right to operate: "Exercising Freedom, in Faith and in Law", Lawyers Weekly (8 March 2013) 4-5. And some legal academics have published short items in support of TWU. See e.g. Iain T Benson, "Law Deans, Legal Coercion and the Freedoms of Association and Religion in Canada" (2013) 71 The Advocate 671; Bradley Miller, "The New Article of Faith for Canadian Law Schools: Same-Sex Marriage", Public Discourse (6 August 2013), online: Public Discourse <http:// www.thepublicdiscourse.com/2013/08/10197/>.

2 The Federation of Law Societies of Canada has constituted a Special Advisory Committee in addition to the usual Approval Committee, after receiving numerous submissions about TWU on issues that were outside the normal considerations of the Approval Committee, Federation of Law Societies of Canada, "National Requirement for Approving Canadian Common Law Degree Programs" (accessed 15/11/2013) online flsc.ca $<$ http://www.flsc.ca/en/national-requirementfor-approving-canadian-common-law-degreeprograms/>

3 Elaine Craig, "The Case for the Federation of Law Societies Rejecting Trinity Western University's Proposed Law School Program" (2013) 25 CJWL 148. See also Jena McGill, Angela Cameron, Elaine Craig et al, "Counterpoint: Why Trinity Western University Should Not Have A Law School", National Post (24 January 2013) online: National Post <http://fullcomment.nationalpost. com/2013/01/24/counterpoint-why-trinitywestern-university-should-not-have-a-lawschool/>.

4 Such petitions have circulated widely within law schools, and media reports suggest that in one week more than one thousand Canadian law students signed a petition asking for TWU to be denied standing as a law school because of its position on sexuality issues: Petti Fong, "Students Sign Petition Against Granting Law School to Christian University", Toronto Star (19 March 2013) online: Toronto Star < http://www.thestar. com/news/canada/2013/03/19/students_sign_ petition_against_granting_law_school_to_ christian_university.html>.

5 On this point in relation to past issues, see the argument of Richard Moon, "The Supreme Court of Canada's Attempt to Reconcile Freedom of Religion and Sexual Orientation Equality in the Public Schools", in David Rayside \& Clyde Wilcox, eds, Faith, Politics and Sexual Diversity in Canada and the United States (Vancouver: UBC Press, 2011) 321 at 337.

6 The culture is of course more secularized at certain elite levels. Secularized elites are often highly disconnected from a much more religious public but nonetheless operate upon and implement their secularized values as the culturally effective ones. On this phenomenon, see generally Stephen L Carter, The Culture of Disbelief: How American Law and Politics Trivialize Religious Devotion (New York: Basic Books, 1993). The claim that today's elite legal and political culture is highly secularized should not of course be taken to exclude the significant emergence of counterforces challenging that secularization. At the same moment when accommodation of religious 
practice is under intellectual challenge (e.g. Brian Leiter, Why Tolerate Religion? (Princeton: Princeton University Press, 2013)), as is religious belief itself (Richard Dawkins, The God Delusion (Boston: Houghton Mifflin, 2006)), there are important intellectual realizations otherwise. See e.g. Robert N Bellah, Religion in Human Evolution: From the Paleolithic to the Axial Age (Cambridge: Belknap Press, 2011) (putting an argument that the place of religion is an exogenous dimension of human history rather than an endogenous aspect determined by factors within); Jürgen Habermas et al, An Awareness of What is Missing: Faith and Reason in a Post-Secular Age (Cambridge: Polity Press, 2010) (beginning to abandon a long-standing exclusion of persons of faith from public reason within the Rawlsian-Habermasian traditions); Thomas Nagel, Mind and Cosmos: Why the Materialist Neo-Darwinian Conception of Nature is Almost Certainly False (Oxford: Oxford University Press, 2012) (leading philosopher of mind challenging inadequacies of materialist explanations of mind); Craig Calhoun, Mark Juergensmeyer \& Jonathan VanAnwterpen, eds, Rethinking Secularism (Oxford: Oxford University Press, 2011) (group of leading intellectuals questioning claims to liberal public sphere as secular).

7 In recent years, Canadian legal academics had overwhelmingly questioned the role of the Federation of Law Societies in setting out criteria for law schools, with some law schools even threatening to defy the Federation's requirements. For an example of the attacks on the FLSC involvement in legal education, see e.g. Harry Arthurs, "Valour Rather Than Prudence': Hard Times and Hard Choices for Canada's Legal Academy" (2013) 76 Sask L Rev 73 at 81-88. This scepticism of the FLSC does not, however, appear to extend to its possible use to attempt to shutter TWU, where some of the same law professors who normally complain about the FLSC want it to come and regulate law schools some more(!).

8 The school's community covenant is available online at <http://twu.ca/studenthandbook/universitypolicies/community-covenant-agreement. $\mathrm{html}>$ and it runs to a number of pages that aspire to various Christian values within a holistic Christian community. Some of these commitments include aspirations such as compassion, humility, and mercy. Others do involve a voluntary commitment by community members to a range of behavioural commitments, including abstention from lying, stealing, hazing, immoderate use of alcohol, and on-campus use of alcohol and tobacco. The controversies have surrounded the voluntary commitment to refrain from "sexual intimacy that violates the sacredness of marriage between a man and a woman." This commitment has been rephrased compared to the phrasing at the time of Trinity Western University $v$ British Columbia College of Teachers, 2001 SCC 31, [2001] 1 SCR 772 [Trinity Western University cited to SCC], consistently with ongoing dialogues on sexuality within Evangelical Christian communities. For the phrasing at the time of Trinity Western University see ibid at para 4.

9 Letter from Bill Flanagan, President, Canadian Council of Law Deans to John Hunter and Gérald Tremblay, President, Federation of Law Societies of Canada (20 November 2012) online: <http://www.ccld-cdfdc.ca/images/news/ CCLDnov20-2012lettertoFederation-reTWU. pdf $>$.

10 Craig, supra note 3. .

11 The dynamics that threaten American law schools simply do not exist in the same form in Canada, and, indeed, a case could be made that there remain too few law school spots in Canada rather than too many.

12 The word "potential" is significant here. Obviously, the record of TWU will depend upon its actions if it is allowed to operate. Ironically, all of the extra hoops being generated for it to be allowed to operate may unwittingly put pressure on it to prove that it is a law school like all the others, when its greatest potential is precisely in offering a different approach to legal education and legal scholarship. Only time will tell how the pressures of accreditation and the potential of a Christian law school interact. Compare Lynn R Buzzard, "A Christian Law School: - Images and Vision" (1995) 78:2 Marq L Rev 267 at 270 ("[a]ccrediting associations add to the pressures to reflect a secular orthodoxy.") There are real dangers present from demands of conformity with other law schools.

13 See generally Michael Hertz, "The Role of One Religiously Affiliated Law School” (2009) 59:1 J Leg Educ 136 (offering an extended discussion of Cardozo).

14 The offices are actually locked up entirely so that one cannot even go to one's office if one attempted to do so: ibid at 144 .

15 Ibid at 144-45.

16 Ibid.

17 Thus, many Evangelical Christian worship services are very non-ritualistic and instead focused on religious teaching and religious community. 
18 I have obviously asserted these points in the form of rhetorical questions out of an absence of definitive empirical study on the point, but I think that those who are honest with themselves will recognize many ways in which Canada's secular law schools are significantly unwelcoming to those of different religious faiths, including Evangelical Christians. Indeed, some of the attacks on TWU surely demonstrate the point.

19 See David A Skeel, Jr, "The Paths of Christian Legal Scholarship” (2009) 12:2 Green Bag 2d 169 at 181 ("[y] oung scholars in secular law schools will fear significant disincentives to producing faith-oriented scholarship early in their careers.") Some have seen Skeel's other work on Christian scholarship as overly critical concerning the current state of Christian legal scholarship: e.g. David S Caudill, "On the Rhetorical Invention of a Failed Project: A Critical Response to Skeel's Assessment of Christian Legal Scholarship" (2010) 40:3 Seton Hall L Rev 971. However, this disagreement does not affect the point from Skeel that I have referenced. It is also worth noting that there is tangible evidence of the bias of secular legal academics against religious scholarship and religiously affiliated law schools: Monte N Stewart \& H Dennis Tolley, "Investigating Possible Bias: The American Legal Academy's View of Religiously Affiliated Law Schools" (2004) 54:1 J Leg Educ 136. This point strikes against any counterproposal that simply introduces more religiously-based scholarship into universally secular law schools and provides a positive reason for the role of an explicitly religious school.

20 See generally Michael W McConnell, Robert F Cochran \& Angela C Carmella, eds, Christian Perspectives on Legal Thought (New Haven: Yale University Press, 2001).

21 This point is discussed in C John Sommerville, The Decline of the Secular University (Oxford: Oxford University Press, 2006). He describes various ways in which common values and human rights traditions cannot be understood without their religious foundations. For an example, consider how to fully understand the American Declaration of Independence's statement that " $[\mathrm{w}] \mathrm{e}$ hold these truths to be self-evident, that all men are created equal, that they are endowed by their Creator with certain unalienable Rights, that among these are Life, Liberty and the pursuit of Happiness" without coming to grips with the underlying JudeoChristian creation story in which each human being is created in the image of God. Marilynne Robinson wisely references this passage, observing that "Jefferson has used Scripture to assert a particular form of human exceptionalism.... What would a secular paraphrase of this sentence look like? In what nonreligious terms is human equality self-evident?...My point is that lacking the terms of religion, essential things cannot be said": Marilynne Robinson, When I Was a Child I Read Books (Toronto: HarperCollins, 2012) at 162-63.

22 See e.g. Brian Tamanaha, On the Rule of Law: History, Politics, Theory (Cambridge: Cambridge University Press, 2004) at 7-15.

23 See e.g. Deut 17: 18-20 (" $[\mathrm{w}]$ hen he takes the throne of the kingdom, he is to write for himself on a scroll a copy of this law, taken from that of the Levitical priests. It is to be with him, and he is to read it all the days of his life so that he may learn to revere the LORD his God and follow carefully all the words of this law and these decrees and not consider himself better than his fellow Israelites and turn from the law to the right or to the left." (NIV)). Later successions included kings alluding to this passage through references to seeking not to turn away from law "to the right or to the left". Though later scriptural texts record the failure of Israelite monarchy to achieve these aspirations, what is important is the statement, radical amidst the patterns of Ancient Near Eastern cultures, that the king must be subject to the law and not above it and not above his fellow citizens, presaging many elements of modern descriptions of the rule of law.

24 Cf. generally Sommerville, supra note 21 (discussing at various points the general corrective to historical understandings available through an engagement with Judeo-Christian traditions).

25 A counterargument could be made that some of these aspirations could be achieved via closer engagement of individuals at secular law schools with religious legal scholarship. However, the point at note 19 stands in that there will remain strong disincentives to scholars elsewhere, and a Christian law school has a unique contribution to make in providing a safe space for Christian scholars, even if some will engage elsewhere. For an interesting example of such engagement within a secular university, consider New York University president John Sexton's thought-provoking course and book John Sexton with Thomas Oliphant \& Peter J Schwartz, Baseball as a Road to God: Seeing Beyond the Game (New York: Penguin, 2013). Those of religious faith who can find especially powerful ways of engaging with secular thought may actually play an important role by being at secular institutions: Skeel, supra note 19 at $180 \mathrm{ff}$. The point that some Christian scholars can and 
will thrive in secular environments does not mean that all will.

26 See the discussion of student experiences about the lack of values orientation in legal education in Jessica J Sage, "Authority of the Law? The Contribution of Secularized Legal Education to the Moral Crisis of the Profession" (2004) 31 Fla St UL Rev 707. See also Buzzard, supra note 12.

27 Sommerville, supra note 21.

28 Ibid at 132.

29 On such trends in Evangelical theology generally, see Loren Wilkinson, "Creation", in Gerald R. McDermott, ed., The Oxford Handbook of Evangelical Theology (Oxford: Oxford University Press, 2010) 116 at 126-27. For an example of a book in the Evangelical tradition on "creation care", see Steven Bouma-Prediger, For the Beauty of the Earth: A Christian Vision for Creation Care, 2nd edn (Grand Rapids: BakerAcademic, 2010). Such theologies are developing around such passages as Job 38-41, which encapsulates both an admiration of the created world in general but also includes even admiration of creatures that serve no human purpose but are simply wonderful in themselves. See also Psalm 104. For a book discussing such passages and building on the creation care tradition generally, see John C Holbert, Preaching Creation: The Environment and the Pulpit (Eugene: Cascade Books, 2011) (discussing Job 38-41 at 31-41 and several Psalms, including Psalm 104, at 20-30). On Christian legal scholarship and environmental law, see also John Copeland Nagle, "Christianity and Environmental Law", in Michael W McConnell, Robert F Cochran \& Angela C Carmella, eds, Christian Perspectives on Legal Thought (New Haven: Yale University Press, 2001) 435.

30 Craig, supra note 3 at 163-65.

31 Ibid at 165.

32 Compare Bryce W Green, "Ends and Means in Legal Education: The Founding of Liberty University School of Law" (2006) 1 Liberty UL Rev 1 at 8-12.

33 I wish to acknowledge here that not all critics of TWU have pursued Craig's line of argument on this point, and I specifically acknowledge Gillian Calder's respectful engagement with the critical thinking offered in Christian education offered in her commentary during the same panel at which the present paper was presented.

34 Joe P Sutton \& Paulo CM de Oliveira, "Differences in Critical Thinking Skills among Students Educated in Public Schools, Christian Schools, and Home Schools", (Paper presented at the
Annual Meeting of the American Educational Research Association, San Francisco, 18-22 April 1995). Counter to the perceptions of many, Christian activist movements in fact engage in very democratic forms of discourse that rely upon critical thinking. For example, Jon A Shields's empirical study determined that "Christian Rights leaders in the pro-life movement overwhelmingly emphasize four important deliberative norms: promoting public civility, practicing careful listening and dialogue, avoiding theological arguments, and embracing moral reasoning," Jon A Shields, The Democratic Virtues of the Christian Right (Princeton: Princeton University Press, 2009) at 44. See also David M Smolin, "Religion, Education, and the Theoretically Liberal State: Contrasting Evangelical and Secularist Perspectives" (2005) 44 J Cath Leg Stud 99 at 113-14 (stating that "[a]s a matter of intellectual capacity, living in God's world also means acquiring a high level of intellectual skill. Thus, an overwhelming majority of American evangelicals would, like American parents generally, wish their children to acquire excellent intellectual and academic skills. Thus, contemporary theorists of Christian education emphasize the attainment of critical thinking, self-expression, and other higher-order intellectual skills, particularly in the high school years. There are several justifications common within the Christian world for pursuit of intellectual skill. First, there is recognition that life within a complex society is aided by such skills. Second, there is a view that critical thinking skills make it easier to see through the deceptive lies and temptations of an often anti-Christian popular and higher culture. Third, there is a general appreciation for the honing of intellectual skills as simply another aspect of human development. Fourth, there is the understanding of higher academic attainment as a path to vocational success. All of these view higher intellectual attainment as completely compatible with living within the world as God has made it.")

35 Cf. also Sommerville, supra note 21 at 128 ("religion may offer perspectives rather than propositions. Jesus, for example, was apparently drawn toward a Socratic mode...It is not an exercise of argumentative power over one's opponent, as in the standard model, but more a model of discovery. Jesus thought, apparently, that his hearers might discover something if they were honest with themselves"); JI Packer, Knowing God (Downers Grove: InterVarsity Press, 1973) at 113 (discussing Christian tradition as finding truth as 
first a quality of persons and only secondarily of propositions).

36 That there are such distinctions is a necessary conclusion from the scriptural text itself with, for example, changes in the ritual law as stated in Exodus 20 effected by the statement in Deuteronomy 12, showing a time-bound character to some ritual law even at different historical time points within the Bible's historical narrative.

37 It also bears noting that there have been very real changes in the Evangelical movement generally. Jim Daly's Focus on the Family is different in its approach than James Dobson's Focus on the Family. There have also been significant discussions within the tradition of the need to move from affective approaches to intellectual approaches in various contexts. A seminal work in this regard was Mark A Noll's The Scandal of the Evangelical Mind (Grand Rapids: Eerdmans Publishing, 1994). See also Bryan T McGraw, "The Doctrine of Creation and the Possibilities of an Evangelical Natural Law", in Jesse Covington, Bryan McGraw \& Micah Watson, eds, Natural Law and Evangelical Political Thought (Lanham: Lexington Books, 2013) 57.

38 On the importance of genre to interpretation of the Biblical text, see e.g. Tremper Longman III, "Form Criticism, Recent Developments in Genre Theory and the Evangelical" (1985) 47:1 Westminster Theol. J. 46. See also e.g. Iain Provan, V Phillips Long, and Tremper Longman III, A Biblical History of Israel (Louisville: Westminster John Knox Press, 2003) at 110-11 (vital use of genre in interpreting object of particular Old Testament texts). For a more popularly oriented text, see also Gordon D Fee \& Douglas Stuart, How to Read the Bible for All Its Worth, 3rd edn. (Grand Rapids: Zondervan, 2003) passim.

39 For a seminal, older work making use of a related distinction, see Packer, supra note 35 at 110 (distinguishing between law, promise, and testimony as different matters within Torah, requiring distinctions in interpretation).

40 There is a distinction to be drawn between this community covenant, related to conduct, and a hypothetical covenant that would require adherence to a particular faith and set of beliefs. I would consider the latter more problematic, as one engaging the very freedom of religion concerns that otherwise would have supported it. There could be various other distinctions drawn, where other sorts of covenants would actually be more challenging. I am indebted to Rod Macdonald for discussion on this point. This said, some others might attempt to challenge the private nature of the school once accreditation is at issue, considering accreditation as a sort of public dimension to a law school. With respect, I do not consider accreditation to change the school into something analogous to part of government. Accreditation simply recognizes the educational content of the programme.

41 See Guy Régimbald \& Dwight Newman, The Law of the Canadian Constitution (Toronto: LexisNexis, 2013) at [22.16] (stating that "approaches to religion that focus on the claims of an individual believer risk undermining the protection of religious groups or the more collective dimension of religion, quite possible negating some of the very purposes of the right." See also Benjamin Berger, "Law's Religion: Rendering Culture" (2007) 45:2 Osgoode Hall LJ 277; Janet Epp Buckingham, "The Fundamentals of Religious Freedom: The Case for Recognizing Collective Aspects of Religion", in Graeme Mitchell, Ian Peach, David E Smith et al, eds, A Living Tree: The Legacy of 1982 in Canada's Political Evolution (Toronto: LexisNexis, 2007) 251.

42 Trinity Western University, supra note 8.

$43 R v N S$, 2012 SCC 72, [2012] 3 SCR 726.

44 See discussion in Régimbald \& Newman, supra note 41 at [22.25] (noting that "[ $\mathrm{t}]$ he middle (and majority) approach of McLachlin CJC describes an approach to dealing with freedom of religion claims that are in conflict with other rights by looking first for a reconciliation with other rights and, if necessary, to a balance in particular circumstances.")

45 Mary Anne Waldron, Free to Believe: Rethinking Freedom of Conscience and Religion in Canada (Toronto: University of Toronto Press, 2013).

46 Ibid at 140. Compare also Dwight Newman, Community and Collective Rights: A Theoretical Framework for Rights Held by Groups (Oxford: Hart Publishing, 2011) at 138 ("Any group seeking respect for its interests...speaks arbitrarily if the claims it makes are not respectful of equally weighty claims that could be made by nonmembers or other groups.")

47 Questions of communities' rights to exclude individuals from membership are challenging ones but unavoidable. For discussion of such questions in some important Canadian contexts, see Sébastien Grammond, Identity Captured by Law: Membership in Canada's Indigenous Peoples and Linguistic Minorities (Montreal: McGill-Queen's University Press, 2009) (entire book focused on issues of membership control). I also discuss these questions in Newman, Community and Collective Rights, supra note 46 at 153-83. 
48 It is clear that there is some boundary between the public and private spheres, whatever challenges may be put against that distinction in some contexts. To take an extreme example, nobody would seriously assert that an individual's choice of dinner guests should be subjected to analysis for whether that individual's method of choosing dinner guests had any methodologies that gave rise to adverse effects discrimination. This example instantiates a point that there is a sphere of intimate association that is beyond analysis in terms of the values that apply to state action, although there can obviously be debate on where the line lies.

49 Stuart White, "Freedom of Association and the Right to Exclude" (1997) 5:4 Journal of Political Philosophy 373 at 374. See also Newman, Community and Collective Rights, supra note 46 at 178-83. None of this argumentation advocates a "right to discriminate", as one objector put it, but a right to association that unfortunately sometimes has discriminatory effects when the values of association and equality run up against one another.

50 This point does not suggest that Canada's secular law schools have an immaculate record in their treatment of those with LGBT identities. However, there cannot be a real suggestion that TWU must modify its rules because of the problems at other law schools, as the more logical way to address problems at other law schools is to address them in reality rather than vicariously.

51 I am indebted to Alvin Esau and Shauna Van Praagh for discussion on this point.

52 I appreciate comments relating to this point from Lorelle Binnion and Gillian Calder.

53 For an example of a challenge to TWU framed within a Christian perspective, see Deborah Howden, “Trinity Western University's IllConceived Message of Exclusion", Editorial, Toronto Star (20 August 2013).

54 This is the overriding conclusion in Trinity Western University, supra note 8, and I do not see any validity to claims that the law has changed in the twelve years since if one thinks about that point within the law.

55 Craig, supra note 3 at 170. See American Bar Association (ABA), 2012-2013 ABA Standard and Rules of Procedure for Approval of Law Schools (Chicago: ABA, 2012), Standard 211, online: American Bar <. http://www.americanbar. org/content/dam/aba/publications/misc/ legal_education/Standards/2013_2014_final_ aba_standards_and_rules_of_procedure_for_ approval_of_law_schools_body.authcheckdam. pdf $>$

56 Controversy concerning Faulkner's application was foreseen by Kristin B Gerdy, "The Irresistible Force Meets the Immoveable Object": When Antidiscrimination Standards and Religious Belief Collide in ABA-Accredited Law Schools" (2006) 85 Or L Rev 943 at 948-49. That such controversy appears not to have materialized arguably evidences that the religious exemptions within Standard 211 do allow for religious freedom in a larger way than Craig implies. 
